Minor parties and Independents in times of change: Scottish local elections 1974 to 2007

Hugh Bochel - University of Lincoln

David Denver - Lancaster University

Department of Policy Studies

University of Lincoln

Brayford Pool

Lincoln

LN6 7TS 


\section{Minor parties and Independents in times of change: Scottish local elections 1974 to 2007}

This article explores the electoral performance of minor party and Independent candidates in Scottish local elections from 1974 to 2007. This is a period which began with a major restructuring of local government and ended with a change in the electoral system from firstpast-the-post to the single transferable vote. It encompasses a second restructuring in the 1990s, the consolidation of the Scottish National Party as an electoral force, and the creation of the Scottish Parliament. Throughout the period, while there have been ebbs and flows, Independents and minor parties have remained significant players in local electoral politics in Scotland.

Independent and minor party candidates have always been a part of the electoral scene but have generally, and perhaps not surprisingly, received relatively little attention from analysts (although there have been some exceptions, such as Rasmussen (1991)). However, at the local level, they have arguably been a significant component of the political landscape (see, for example, Rallings and Thrasher, 1997; Copus and Clark, 2007). This article outlines the levels of participation and the electoral impact of 'minor party' and Independent candidates in elections for Scottish local authorities since 1974.

The elections of 1974 took place following a major restructuring of local government in Scotland under the Local Government Scotland Act 1973, which resulted in a twotier system for all of the country, other than the three main island groups - the Orkneys, Shetlands and Western Isles. Here, 'Island Councils' were created as singletier authorities to serve the small, geographically dispersed populations. On the mainland, the 53 lower tier district councils were responsible for local services including social housing. They varied enormously in population (electorates ranged from less than seven thousand in Nairn to nearly two-thirds of a million in the city of Glasgow) and geographically from concentrated urban areas to large rural areas with small and dispersed populations. The nine larger regional councils were responsible for services such as education and social work. They also varied widely in geographic size (Central covering around 260,000 hectares and Highland around 2,600,000 hectares) and population (1974 electorates ranging from nearly 1.8 million in Strathclyde to 75,000 in Borders). This system remained in place until 1995 when it was replaced by a system of single-tier, unitary authorities. Until 2007 all local elections took place on the basis of single member wards and the first-past-the-post electoral system, but for 2007, following an agreement between Labour and Liberal Democrats to form a coalition administration after the 2003 Scottish Parliament elections, this was replaced by the single transferable vote, with wards electing three or four councillors.

The analysis which follows draws upon the collection of Scottish local election results since 1974, begun by John Bochel and David Denver, and continued more recently by David Denver and Hugh Bochel. Local elections have taken place in Scotland in May of the following years, for each of which full data are available (some of this data is 
also held at the Data Archive - SN 5319 - British Local Election Database, 18892003).

$\begin{array}{ccc}\text { District Councils } & \begin{array}{c}\text { Regional and } \\ \text { Island Councils }\end{array} & \begin{array}{c}\text { Unitary } \\ \text { Councils }\end{array} \\ 1974 & 1974 & 1995 \\ 1977 & 1978 & 1999 \\ 1980 & 1982 & 2003 \\ 1984 & 1986 & 2007 \\ 1988 & 1990 & \\ 1992 & 1994 & \end{array}$

We are able, therefore, to provide as complete coverage as is likely to be possible of the participation and performance of Independents and minor (and indeed major) parties in Scottish local government over a thirty-three year period. Given the subject matter, the time period and the lack of requirement for 'parties' to be registered for the bulk of this period, there may be some discrepancies in the way that parties are described and candidates' allegiance attributed by those who have collected the data. Given that the overwhelming bulk of the work has been undertaken by three individuals, however, these variations are likely to be less problematic than with many datasets.

In 1974 the elections for both district and regional tiers were held in the same year, and in 1999, 2003 and 2007 council elections were held on the same days as elections to the Scottish Parliament, which overshadowed their local counterparts. These coincident elections affected levels of turnout, and may have affected patterns of voting and possibly candidature, although it is hard to identify any impact on the pattern of candidatures by Independents or minor parties or, indeed, on votes cast for them. In no year have Scottish local elections coincided with a general election in the United Kingdom, although in 1974 they came between two general elections, in February and October, and in 1992 followed one month after the general election.

\section{CATEGORISING INDEPENDENTS AND 'MINOR PARTIES' IN SCOTTISH LOCAL ELECTIONS}

It is clearly easier for Independents and minor parties to contest local rather than general elections, particularly given that for the bulk of this period there was no requirement to register as a party and that the barriers to local election candidature are lower than for parliamentary general elections. As we have previously suggested:

Local elections provide an opportunity for a range of minor parties, localised groups, and concerned, aggrieved or eccentric individuals to bring their points of view to the attention of the electorate. Unlike parliamentary elections there is no deposit to be forfeited in local elections should a candidate receive only a minimal level of support. Providing that an individual can obtain the signatures of ten electors consenting to his nomination he can stand for election (Bochel and Denver, 1977: 11-12). 
Not only is local government arguably more accessible for Independents and minor parties but their impact can also be greater, with electoral success potentially providing some influence on local decision making. Such opportunities are likely to have been enhanced in those places and at those times when authorities have no party in overall control.

Of course, there may be arguments about what constitutes both 'Independents' and a 'minor party'. Although the requirement of the Political Parties, Elections and Referendums Act 2000 is that only candidates standing on behalf of a registered political party are allowed to use a description on a ballot paper at an election, this has only applied to the 2003 and 2007 elections of those considered here. For present purposes therefore, an 'Independent' is taken to be a person who describes themselves as such on the ballot paper (or, in a very small number of instances, who provides no description), while 'minor party' candidates include all of those who stand for local government elections who have not described themselves as Independent or in terms of one of the 'big four' political parties in Scotland: the Conservatives, Labour, Liberal Democrats (including, previously, Liberals and, for a time, representatives of the Social Democratic Party (SDP)) and the Scottish National Party (SNP).

There are a variety of ways in which Independents and 'small' or 'minor' parties can be conceptualised and categorised - by ideology or size, for example (see Copus and Clark, 1997; Müller-Rommel, 1991; Smith, 1991). These frequently draw upon and relate to classifications of parties at the national level and it is not our intention to pursue this approach to any great extent, particularly as it is difficult to apply such classifications systematically to Scottish local politics. For a significant proportion of the 'parties' considered here, many of which were clearly extremely small (sometimes presumably only individuals or handfuls of people) and short-lived, and which would be unlikely to fit most definitions of what constitutes a political party, it is simply not possible to know enough about them to make a detailed classification. Rather, a brief categorisation is given based upon the most obvious characteristics of those who have been candidates in Scottish local elections since 1974. We suggest four main categories with some further divided into sub-categories.

1. Those who describe themselves as 'Independent', deliberately avoiding party labels. Over the period from 1974 to 1999 there was generally a slow but steady decline in the proportion of candidates and councillors from this group, although more recently the proportion of Independent candidates has again increased. Copus and Bottom (2007) have argued that for England there are three types of Independent, all of which are likely to occur in Scotland. These are, firstly, the 'fully independent', who has no supporting organisation and does not join in any formal group with other councillors. Secondly, the 'conjoined independent', who may join groups of Independent councillors, which may act in some ways that are similar to those of parties. Thirdly, the 'revealed independent', who stands as an Independent candidates but maintains some party affiliations. In the latter group Copus and Bottom include 'revealed party independents', but here they are treated separately.

2. Minor parties. As with Independents, recent elections have seen an increase in the proportion of candidates representing minor parties. Some of these have existed effectively in name only, while others have clearly displayed most or 
all of the characteristics normally associated with political parties. It is therefore worth identifying a number of sub-categories, none of which are mutually exclusive, but which may help inform our understanding of their involvement in Scottish local elections:

a. Genuine minor parties such as the Communist Party, which was of long standing but never became more than a minor party, and effectively faded from the scene during this period. Others have emerged and developed both nationally and locally over the period, and some, such as the Scottish Socialist Party, have stood for and gained representation at other levels, such as the Scottish Parliament.

b. Nascent or embryonic major parties, as would have been the case, for example, with the SNP during the 1950s and 1960s (for example, McLean, 1970; Bochel and Denver, 1972) and perhaps the Ecology Party/Greens during the period considered in this article.

c. Parties based in a specific locality with a specifically local focus, of which there are a small number, such as the Paisley Local Party in 1974, through the Shetland Movement, which fought and won seats from 1986 to 1994, to the Borders Party and the East Kilbride Alliance in 2007.

d. 'Splinter' parties - those which have largely been formed by breakaways of members of a larger party, such as Scottish Militant Labour in the early 1990s, and the small rump that stood as SDP when the bulk of their party merged with the Liberals to form the Liberal Democrats.

3. Organisations which might arguably better fit with the idea of 'political associations' or 'voter associations' than political parties. There are two types, neither of which have been particularly common over the period. On the one hand, there are some relatively isolated examples of groups such as Ratepayers' Associations or, less frequently, Residents' or Tenants' Associations, and, on the other, a small number of other groups that have been primarily concerned with single issues, such as the Drumchapel Anti Poll Tax Group in 1988 and Local Hospital Action and Local Health Concern in 2007.

4. As noted above, there are those whom Copus and Bottom (2007) term 'revealed independents', such as Independent Conservative and Independent Labour candidates. These are generally individuals (rather than 'splinter' groupings) who use the 'independent' label but in conjunction with a party name (or that of a political position such as 'socialist'). They have often fallen out with the party concerned, whether over a matter of principle or on other grounds, and may compete against it. The numbers of candidates of this type peaked in Scotland in the 1970s but declined thereafter. This might be for a number of reasons. Perhaps the parties changed and sought to become more inclusive (or simply found it harder to get sufficient candidates so that deselection of existing councillors became less common). Possibly some of 
the 'splinter' parties or other more coherent minor parties that emerged became homes to individuals disillusioned with their previous parties.

Whilst it clearly does not alter the category into which parties might fall, there is one other feature of some of the minor parties that have existed in Scotland over this period, and that is that a few have been closely associated with charismatic individuals, such as Jim Sillars and the Scottish Labour Party in the late 1970s, and perhaps Tommy Sheridan and the Scottish Socialist Party from around 1999 to 2006, and their fortunes have closely mirrored those of these leaders.

One final point that is worth making in the context of local politics in Scotland is that in some areas some or all of the 'big' parties are 'minor' parties. The nature of local politics in some councils means that even established parties can struggle to find both candidates and electoral support. For example, even with the single transferable vote system in place in 2007, Labour contested only two of the 14 wards in the Scottish Borders and received only 1.9 per cent of first preference votes; the Conservatives received only 7.5 per cent of first preference votes in North Lanarkshire and 7.6 per cent in both Glasgow and West Dunbartonshire; and the Liberal Democrats had no candidates in East Ayrshire or South Ayrshire. Only the SNP received more than 15 per cent of the vote in every mainland council. In the Island councils all of the main parties were effectively minor parties or, indeed, did not compete at all in the 2007 council elections. This is despite the elections taking place on the same date as the Scottish Parliament elections, which might have been expected to have had some 'nationalising' effect on the council elections.

An alternative way of considering 'minor parties', and perhaps particularly very minor or local parties, is to examine their persistence, both across local government boundaries and over time. Where the latter is concerned, very few of the minor parties (other than 'revealed independents') that have competed in Scottish local elections over the last three decades appear to have had electoral lives of more than ten years. There were Communist (or equivalent, such as Democratic Left) candidates at every election from 1974 to 2003 and Ecology/Green candidates have appeared in most elections since 1980, although with large variations in numbers. There have been sporadic appearances of 'Liberal' candidates since the original party's merger with the SDP, with a core of activists, particularly in Edinburgh, contesting elections from 1990 to 2003, and there have been a number of 'Moderates', for example in Cunninghame in the 1980s. Other than that, there have been sundry groupings such as Residents' Associations and Ratepayers' Associations, some of which, such as the Ratepayers' Association in Kirkcaldy, clearly existed for a period of time.

A similar pattern occurs for minor parties competing across local authority boundaries, whether it is across geographic boundaries in the same set of elections, or, prior to 1999, across district and regional elections. A small number have fought at both district and regional level (notably the Communist Party and Democratic Left, the Greens and the Liberal Party (again, largely in Edinburgh)), while a slightly larger number have fought European, general or Scottish Parliamentary elections, such as the Communist Party, the Greens, and more recently the Natural Law Party, the Scottish Socialist Party, and UKIP. 


\section{INDEPENDENTS AND MINOR PARTIES IN SCOTTISH LOCAL ELECTIONS}

It is sometimes suggested that the period prior to the 1974 reorganisation of local government - when there were more and smaller local authorities - saw greater involvement on the part of organisations such as Ratepayers' and Residents' Associations in elections. It is difficult to be sure whether or not the 1974 changes precipitated a step change in the participation of minor party candidates in Scottish local elections. However, although it provides an indicative, rather than definitive, answer, an analysis of some pre-1974 local election results published in The Scotsman and The Glasgow Herald suggests more continuity than change. In each of Scotland's four major cities, Aberdeen, Dundee, Edinburgh and Glasgow the main 'minor party' presence in 1970 and 1971, as in 1974, was the Communist Party, although in Aberdeen the Progressives put up a number of candidates in opposition to official Conservatives. There were few other candidates standing under anything other than the major party or Independent labels. Similarly, in other burghs, at the 1971 elections the only minor party candidates to appear as anything other than individuals were 9 Moderates (4 of whom were elected in Ayr while 2 were returned unopposed in Dumfries and 1 in Girvan), 13 Ratepayers Association (4 elected in Linlithgow and 1 in Musselburgh, while a further two were unopposed in Musselburgh and Kirkcaldy), and 2 MIA candidates who were elected unopposed in Perth. This evidence therefore suggests that the pattern of candidature by minor parties in the early 1970s was not significantly different from that in 1974. For Independents, however, the disappearance of the smaller burgh councils and the greater participation of the major parties in many of the new authorities, probably contributed to a decline in candidates and their electoral fortunes.

There is no simple way to summarise the number and impact of minor parties and Independents in Scottish local elections since 1974. For example, share of the vote is unsatisfactory because for part of this period there were significant numbers of uncontested wards, particularly in the more rural authorities, while the discrepancies in terms of electorates, varying from the low hundreds in some wards in the Islands councils before 2007 to more than 20,000 in some wards in Glasgow, are also unhelpful. In addition, varying patterns of competition by the major parties impact significantly on the shares of the vote for minor parties and Independents. A further complication is the fact that elections for regional councils from 1974 to 1994 were held on a four-year cycle while for district elections from 1974 to 1980 there was a three-year cycle and then from 1984 to 1992 a four-year cycle. From 1995 the unitary councils have been elected on a four-year cycle, but in 2007 the electoral system changed from first-past-the-post to the single transferable vote. Deciding how any analysis is best presented, therefore, is itself difficult.

We begin, however, with some basic figures. Since 1974 candidates for Scottish local authorities, excluding those from the four major parties, have used around one hundred different descriptions of themselves on ballot papers, but, while the number of candidates has changed significantly, the number of 'labels' used at each election has generally not varied enormously (Table 1).

Table 1: Number of labels used by non-major party candidates 


\begin{tabular}{|c|c|c|c|c|c|c|c|c|c|c|c|c|c|c|}
\hline $\begin{array}{c}1974 \\
\text { Reg/Dist) }\end{array}$ & $\begin{array}{l}1977 \\
\text { (Dist) }\end{array}$ & $\begin{array}{l}1978 \\
\text { (Reg) }\end{array}$ & $\begin{array}{l}1980 \\
\text { (Dist) }\end{array}$ & $\begin{array}{l}1982 \\
\text { (Reg) }\end{array}$ & $\begin{array}{l}1984 \\
\text { (Dist) }\end{array}$ & $\begin{array}{l}1986 \\
\text { (Reg) }\end{array}$ & $\begin{array}{l}1988 \\
\text { (Dist) }\end{array}$ & $\begin{array}{l}1990 \\
(\operatorname{Reg})\end{array}$ & $\begin{array}{l}1992 \\
\text { (Dist) }\end{array}$ & $\begin{array}{l}1994 \\
\text { (Reg) }\end{array}$ & 1995 & 1999 & 2003 & 2007 \\
\hline 19 & 23 & 11 & 17 & 21 & 15 & 15 & 26 & 16 & 14 & 18 & 15 & 18 & 21 & 16 \\
\hline
\end{tabular}

Figure 1 gives a rough depiction of overall trends in candidatures and seats won. It shows, for district council elections from 1974 to 1992 (the general trend is similar for regions) and for the new councils from 1995 to 2007, the percentage of candidates from minor parties and Independents and the percentage of seats won at each election by minor parties and Independents. Starting with candidates, the first twenty years show a fairly steady decline in the percentage of Independent and minor party candidates, while the period since 1999 has seen something of a revival for both. In terms of the number of seats won, for Independents there is also a long-term decline and for minor parties performance is generally poor throughout the period. The best performance of the latter in terms of seats won was 2 per cent in 1977 (with 7 successful Ratepayers Association and 4 Independent Labour candidates, as well as a smattering of seats for those standing under other labels). There has clearly been something of a resurgence in the proportion of Independent and minor party candidates in 2003 and 2007, but for the latter elections, although there was a real increase in numbers, as discussed below, the increasing percentage of candidates who are Independents or from minor parties also reflects the decisions by the major parties to put forward fewer candidates in the multi-member STV wards than they had done in the previous single-member wards. It may also be the case that the more proportional outcomes expected under STV itself encouraged more small party and independent candidates.

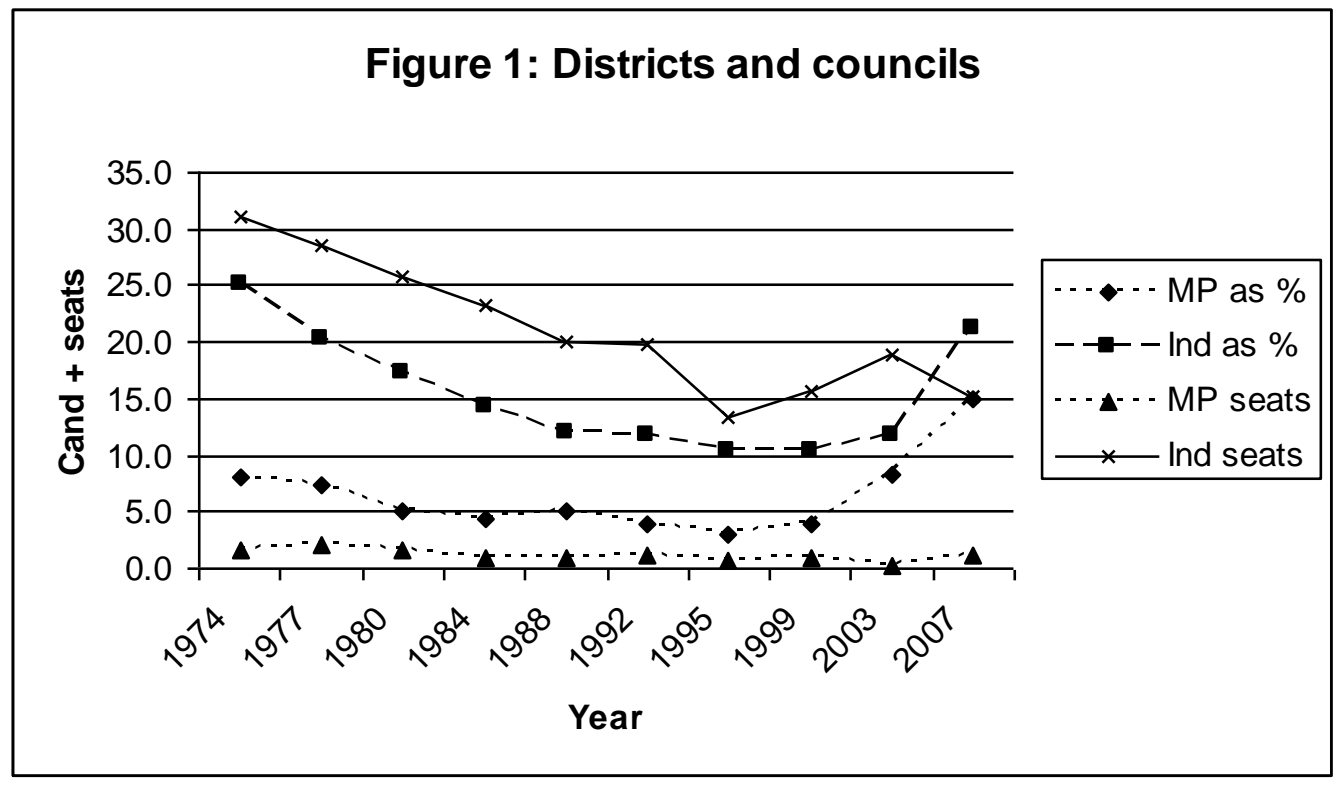

\section{Candidates}

A relatively simple measure of electoral activity is the number of candidates put forward. Beginning with elections to the regional councils (Figure 2) it is clear that there was a period of decline in Independents and minor party candidates from 1974 to 1982 , followed by an increase and then another fall. In terms of the patterns of 
contestants, from 1974 to 1994 the regions saw a fairly slow but steady decline in the number of candidates standing as Independents, a decline in the number of

Communist candidates, and a surge in the number of Ecology/Green Party candidates in 1986 and 1990 (particularly in Lothian and Strathclyde), followed by a fall in 1994.

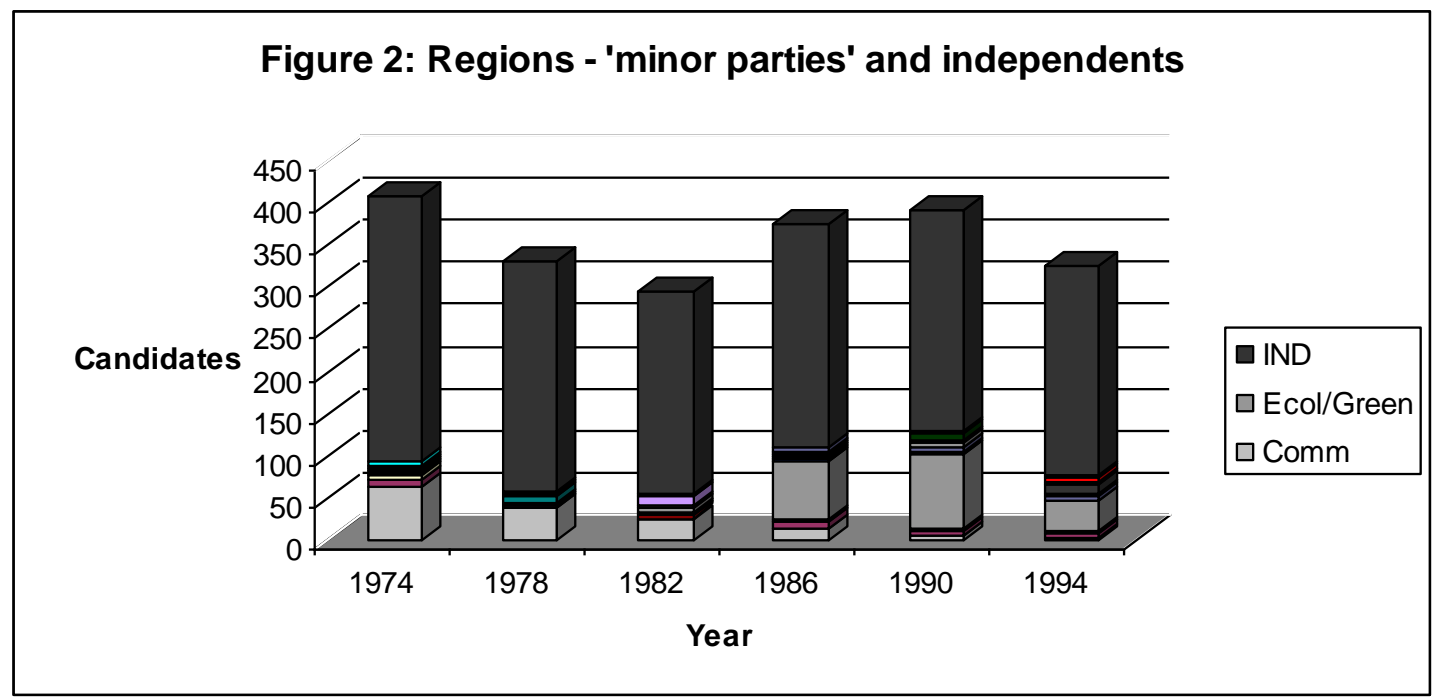

Over this period no other grouping made much of an impact, although there was a constant smattering of 'independent party' or 'revealed independent' candidates, particularly those standing as Independent Labour, but also Independent Liberals, Independent Conservatives/Progressives, and Independent Nationalists. There were also some 'left-splinter' parties, such as Scottish Militant Labour which contested 12 seats in 1994.

Looking at the district councils (Figure 3) there is a slightly different pattern with regard to Independent candidates, with the numbers ebbing and flowing, but remaining higher in 1992 (368) than in 1974 (345), although significantly lower than the peak of 1977 (521). With regard to minor parties the pattern is roughly similar to that of the regions, with the number of Communist candidates falling steadily from 130 in 1974 to only one in 1992, and with the number of Ecology/Green candidates rising from 7 in 1980 to 77 in 1992.

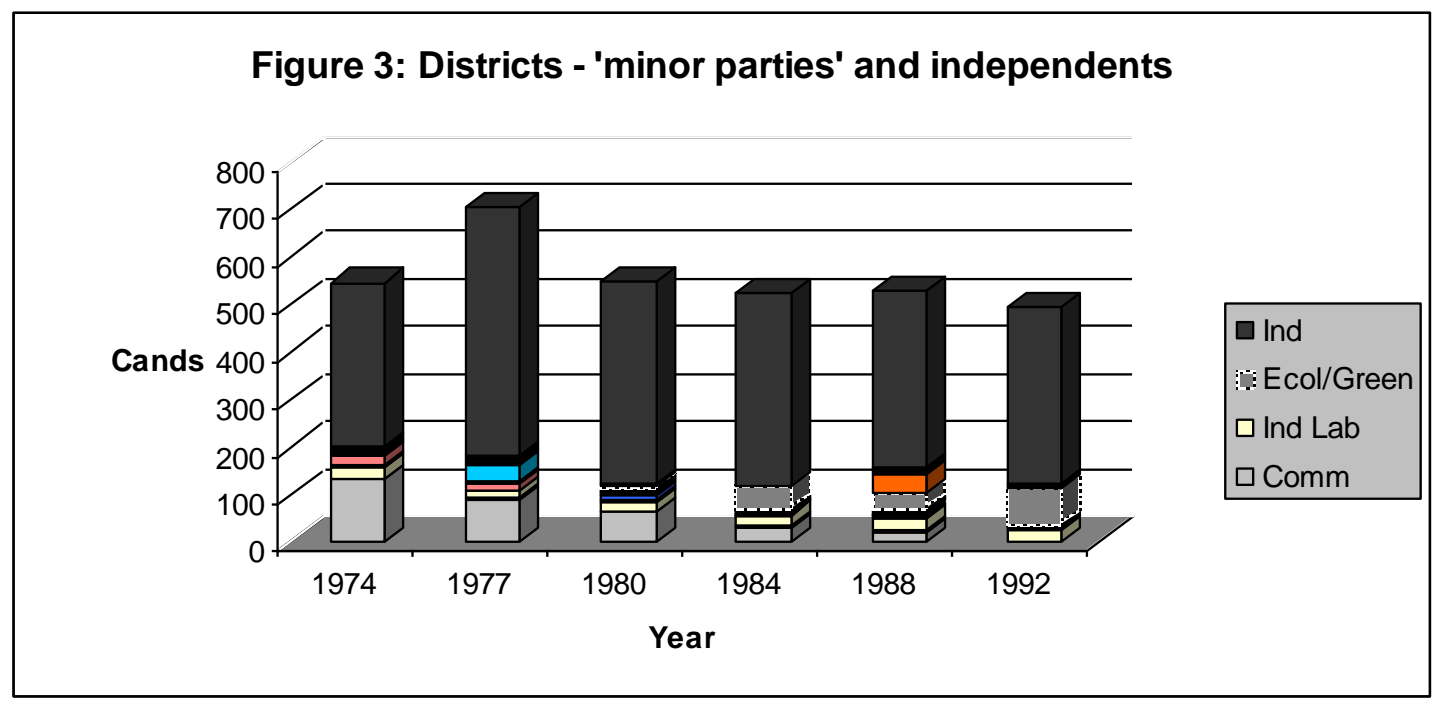


In relation to minor parties it is also possible to see some patterns that, while they may exist at the regional level, are perhaps masked by the smaller number of candidates. Examples are the demise of Ratepayers Association candidates, the brief life of the Scottish Labour Party (35 candidates in 1977 but only four in 1980), the attempt to continue in the name of the SDP (26 candidates in 1988), and the persistence of 'independent party' candidates. Among the latter, although there were also Independent Conservatives, Liberals, Nationalists and even an Independent Green, Independent Labour candidates were the most common at almost every election and were generally the most successful.

Moving on to the unitary councils now in place, perhaps slightly surprisingly there has been an increase in the number of people standing as Independents, from 361 in 1995 to 434 in 1999, 485 in 2003 and 581 in 2007 (Figure 4). From Figure 4 the obvious developments among the minor parties are the disappearance of the Greens in 1999 and 2003, with a re-emergence in 2007, and, despite the more or less complete disappearance of Communist candidates, the increase in the number of candidates from left parties - Scottish Militant Labour in 1995, the Scottish Socialist Party from 1999 (albeit falling back in 2007) and Solidarity in 2007. In contrast to the previous elections in the regions and districts, 'independent party' candidates more or less disappeared, with no Independent Labour candidates in either 2003 or 2007.

However, just as we cannot credit the introduction of STV alone with encouraging more Independent candidatures (although the argument is plausible), it cannot be said that the changed system discouraged 'independent party' candidates.

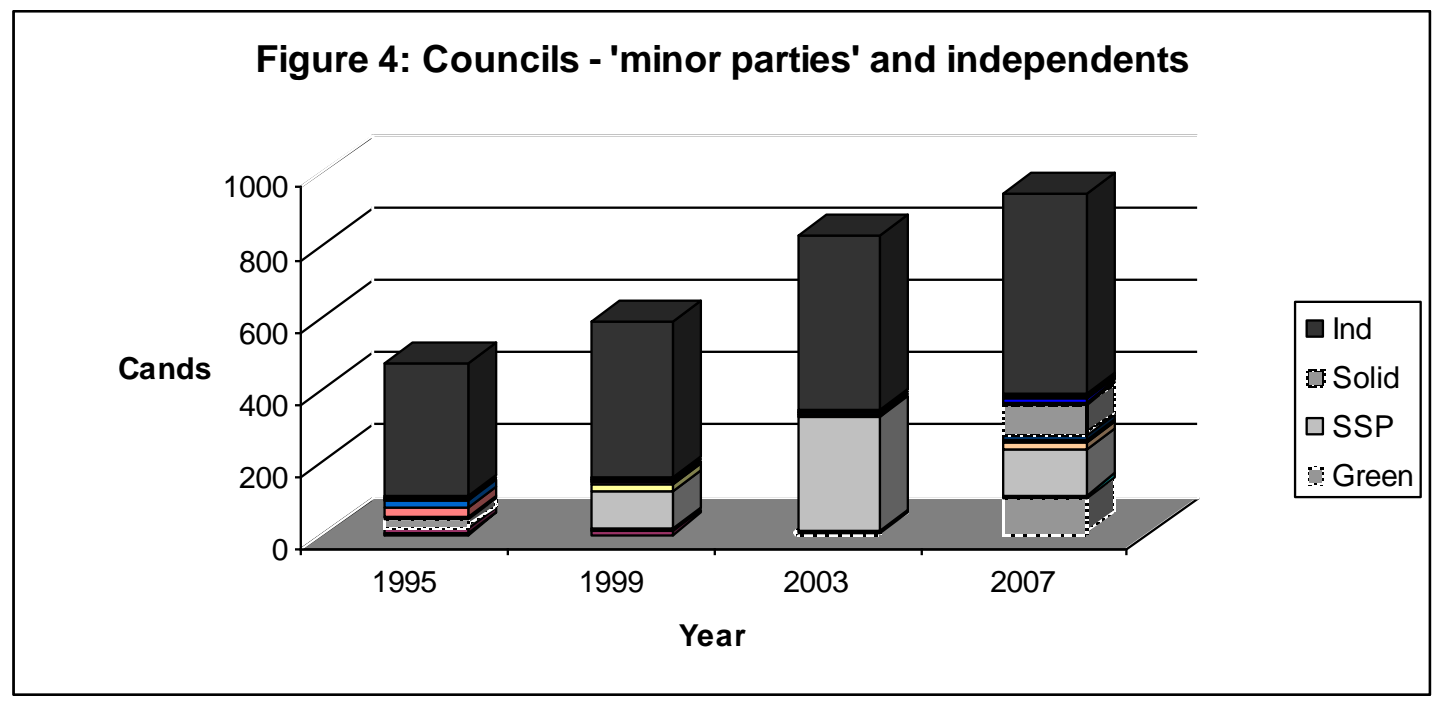

Perhaps the frequently discussed disillusion with mainstream politics is one factor behind the increase in the numbers of minor party and Independent candidates in recent years. However, given that there has been evidence of disillusion for many years, this may not be an entirely adequate explanation. There is clear evidence, however, that the major parties have been suffering from falling membership and weakening local organisation (Clark, 2008) and this may partially explain why minor parties are able to attract more candidates. 
There is a clear geographical dimension to the candidatures of Independents and minor parties. While most elections have seen Independent candidates across Scotland there have been significant geographical differences. In 1974, for example, 46 of the 47 wards in Highland region were contested by Independents (indeed 91 of the 129 candidates were Independents), 28 out of 53 in Grampian (44 out of 103 candidates), and 33 out of 35 in Dumfries and Galloway (64 out of 78 candidates). On the other hand, only 16 of 103 wards in Strathclyde were contested by Independents (20 out of 326 candidates), 7 out of 49 in Lothian ( 7 out of 134 candidates) and 7 out of 42 in Fife (10 out of 95 candidates). Even in 2003, despite increased participation by the major parties, a similar, although weaker, pattern remained. Independents contested 86 per cent of wards in Argyll and Bute (46 out of 109 candidates), 81 per cent in Moray (28 out of 78 candidates), 68 per cent in Highland (108 of 170 candidates), 59 per cent in Angus (18 out of 117 candidates) and 56 per cent in the Scottish Borders (23 of 99 candidates). In contrast, 9 authorities had fewer than ten per cent of wards contested by Independents. The Islands councils have generally been dominated by Independents, and this continues to be the case.

There has also been geographic clustering of minor parties throughout the period, and not simply for those with a particular local focus. The Communist Party, for example, tended to contest seats in authorities within the Fife and Strathclyde regions, and to a lesser extent within Lothian. Other 'left' parties, whether splinter parties such as Scottish Militant Labour, or nascent or embryonic parties, such as the Scottish Socialist Party and Solidarity, have tended to focus on Glasgow, Edinburgh and to some extent Dundee. The Greens too, have tended to concentrate their candidatures in Edinburgh and, more recently, Glasgow.

\section{Share of the vote and seats won}

In terms of electoral success, as previously noted (Figure 1), minor parties have performed relatively poorly, perhaps in part due to the effects of the first-past-the-post electoral system. The introduction of STV in 2007 might have been expected to have some impact on this, but did not, either because the 3 or 4 member ward structure limited the degree of proportionality, or simply because of a lack of electoral support.

In terms of share of the vote, Table 2 shows that Independents, and to a lesser extent minor parties, tended to perform better in district rather than regional elections, but also that the last two sets of election, for the single-tier councils, have seen a marked increase in the share of the vote going to both groupings. For minor parties this may be largely attributable to an increase in the proportion of candidates, and particularly the presence and performance of genuinely minor parties with significant support, such as the Scottish Socialist Party and the Greens. Similarly, 2003 and 2007 saw increases in the number of Independent candidates, but there has also clearly been an increase in the proportion of the electorate willing to vote for them. However, other evidence suggests that minor party and Independent candidates do not appear to have been significant recipients of vote transfers under the STV system.

Table 2: Share of vote

$$
\begin{array}{cccccccccccccc}
\mathrm{D} & \mathrm{R} & \mathrm{D} & \mathrm{R} & \mathrm{D} & \mathrm{R} & \mathrm{D} & \mathrm{R} & \mathrm{D} & \mathrm{R} & \mathrm{C} & \mathrm{C} & \mathrm{C} & \mathrm{C} \\
1977 & 1978 & 1980 & 1982 & 1984 & 1986 & 1988 & 1990 & 1992 & 1994 & 1995 & 1999 & 2003 & 2007^{*}
\end{array}
$$




\begin{tabular}{|c|c|c|c|c|c|c|c|c|c|c|c|c|c|}
\hline Independents & 9.8 & 4.9 & 6.7 & 5.1 & 6.8 & 4.8 & 6.1 & 4.5 & 7.3 & 4.7 & 7.6 & 7.2 & 10.1 \\
\hline Minor parties & 3.3 & 1.9 & 2.2 & 0.6 & 1.6 & 1.1 & 2.4 & 3 & 1.9 & 1.5 & 1.5 & 1.7 & 3.6 \\
\hline
\end{tabular}

*Share of first preference votes

As with candidatures, there is also a geographic pattern to the limited electoral success of minor parties. For example, while the Communist Party put up candidates in a number of authorities, its few electoral successes were largely confined to the former coalfields of Fife. At the district level, Kirkcaldy, also in Fife, saw Ratepayers Association candidates being elected in the early years of this period. Later in the period, left-wing parties such as Scottish Militant Labour, the Scottish Socialist Party and Solidarity, won their seats in the industrial areas of the West of Scotland, and particularly Glasgow. Under STV in 2005 the Greens won seats in Edinburgh and Glasgow.

For Independents too there is a clear geographical pattern, with the bulk of Independent candidates over the period contesting seats in the less partisan rural areas. Nonetheless, the last two rounds of elections in 2003 and 2007 saw increases in the number of Independent candidates in a number of councils outside these areas, including Angus, Fife and Edinburgh. In 2007 in particular, with the new multimember wards, there was a big increase in the percentage of wards contested by Independents, so that it was not only in councils such as Highland and Moray that all seats were fought by Independents, but also others including Falkirk and Inverclyde.

\section{Party systems}

There are clearly a number of ways in which party systems can be defined, but here we will use that suggested by Bochel and Denver (1977) in relation to Scottish local government. 'Partisan' authorities are those where Independents gain twenty per cent of seats or less; 'non-partisan' authorities are those where Independents gain eighty per cent of seats or more; and others are classed as 'intermediate'. Given the limited electoral success of minor parties, they have had little impact upon party systems within Scottish local government. In contrast, Independents have had a much more immediate effect in some areas. Using this typology, in 1974 and 1977, at the district level, 26 districts were 'partisan', 13 districts were 'non-partisan', and 14 were 'intermediate'. However, even in this period the 'non-partisan' districts were concentrated on the Scottish periphery, being in Highland or Grampian regions in the north, and Borders and Dumfries and Galloway regions in the south, and contained less than nine per cent of the Scottish electorate. By 198032 districts could be classed as 'partisan', 7 as intermediate, and 14 as 'non-partisan', a pattern which remained roughly the same up to the final district elections in 1992 when 34 districts were partisan, 9, intermediate and 10 non-partisan.

At the regional level, even by 1978, no area, other than the three Island councils, fell strictly within such a 'non-partisan' definition, although in Highland, Borders and Dumfries and Galloway Independents did win more than seventy per cent of seats. Independents continued to dominate these regions up to the final set of elections in 1995 when, for the first time, the main parties won more than half of the seats in the 
Borders and Dumfries and Galloway, leaving Highland as the one region with an overall Independent majority.

If we look simply at control of councils, the period from 1974 to 1994 saw Independents dominate the three Islands councils, and generally Highland, Borders and Dumfries and Galloway. However, at the district level the number of authorities with an Independent majority fell from 21 to 14 . The number of councils with no party in overall control has fluctuated, and this was particularly apparent within the districts, where there were 13 councils in this category in 1974 and 15 in 1997, but only 4 in 1980, although the figure rose again to 13 in 1992.

When the first elections for the new unitary authorities were held in 1995, only three of the 29 councils returned a majority of Independent councillors (Argyll and Bute, Borders and Highland) (although the three Island councils, elected the previous year, also had Independent majorities), while in Dumfries and Galloway Independents were the largest 'grouping'. The number of councils with no overall control rose from 3 in 1995 to 10 in 1999 and 11 in 2003. In 2007, under STV, only the three Island councils had an Independent majority, and only two authorities, Glasgow and North Lanarkshire gave a single party (Labour) a majority.

\section{CONCLUSIONS}

This article has explored the involvement of Independent and minor party candidates in Scottish local elections over the past three decades. It has served to highlight the variety of guises under which candidates, other than those from the four main parties, have contested elections. It is apparent that, in general terms, Independent candidates have made more of an impact over the period than have those from minor parties, both in terms of the numbers of candidates and of seats won. There have been significant geographic variations in the levels of candidatures and in electoral performance of Independents, with the greatest proportions and the highest success rates coming in the more rural, less partisan areas. In Scotland's major urban centres, Independent candidates have been less common and have fared less well. In contrast, minor party candidates, and particularly those from the left and the environmental movement, have tended to be concentrated in the urban conurbations or former mining areas, which is also where they have tended to achieve any limited electoral success.

Small parties can be seen as providing new channels of engagement and participation. Arguably, they may fill 'gaps' or 'spaces' if the major parties fail to reflect the views of the public or if the public become dissatisfied with major parties. Independents too may be seen as fulfilling such a role, as well as enabling individuals and electors who may not feel an affiliation to any party to engage with the political system. Similar arguments can be made about the perceived disengagement of the public with politics which appears to reflect discontent with major parties, and discontent with parties per se (and perhaps also with politics and politicians more generally). Belanger (2004) has argued that 'third' or 'minor' parties can 'benefit from popular dissatisfaction with the functioning of party-based democracy' (p. 1073) and in that sense could potentially serve to provide some continued basis for the legitimacy of democratic systems based upon party politics. 
In relation to such arguments, the increase in the proportions of candidates from Independent and minor parties at the 2003 and 2007 elections is an interesting phenomenon. Although it has not resulted in any significant improvement in the number of council seats won, the increased share of the vote taken by both groups, suggests that the pattern of continual change over the past thirty years will continue, and that there is the potential, particularly with the adoption of STV (albeit with wards of 3 or 4 members limiting the extent of proportionality), for greater electoral success for such candidates in future. 


\section{REFERENCES}

Bélanger, É., 2004, 'Antipartyism and Third-Party Vote Choice: A Comparison of Canada, Britain and Australia', Comparative Political Studies, 37/9, 1054-1078.

Bochel, H. and Denver, D., various years, Scottish Council Elections (Dundee: Election Studies).

Bochel, H. and Denver, D., 2007, Scottish Council Elections 2007 (Lincoln: University of Lincoln).

Bochel, J. and Denver, D., 1972, 'The Decline of the SNP - An Alternative View', Political Studies, 20/3, 311-6.

Bochel, J. and Denver, D., various years, Scottish District Elections (Dundee: Election Studies).

Bochel, J. and Denver, D., various years, Scottish Regional Elections (Dundee: Election Studies).

Clark, A., 2008, 'Mass, Cadre or Franchise Parties? Assessing Scotland's Local Party Organisations', Journal of Elections, Public Opinion and Parties, 18/1, $27-51$.

Copus, C. and Bottom, K., 2007, 'Small Parties, Independents and Political Associations in Local Politics', paper presented to the Elections, Public Opinion and Parties Annual Conference, University of Bristol, 7-9 September.

Copus, C. and Clark, A., 2007, 'A Sign of the Anti-Party Times? Typologising Small Parties and Independents in British Local Politics', paper presented to the Political Studies Association Annual Conference, University of Bath, 11-13 April.

McLean, I., 1970, 'The Rise and Fall of the Scottish National Party', Political Studies, 18/3, 357-72.

Müller-Rommel, F., 1991, 'Small Parties in Comparative Perspective: The State of the Art', in Müller-Rommel, F. and Pridham, G. (eds), Small Parties in Comparative and National Perspective (London: Sage).

Rallings, C. and Thrasher, M., 1997, Local Elections in Britain, (London: Routledge).

Rallings, C., Thrasher, M. and Denver, D., 2005, 'Trends in Local Elections in Britain, 1975-2003', Local Government Studies, 31/4, 393-413.

Rasmussen, J., 1991, 'They Also Serve: Small Parties in the British Political System', in Müller-Rommel, F. and Pridham, G., Small Parties in Comparative and National Perspective (London: Sage).

Smith, G., 1991, 'In Search of Small Parties: Problems of Definition, Classification and Significance', in Müller-Rommel, F. and Pridham, G., Small Parties in Comparative and National Perspective (London: Sage). 
Minor Parties article final 08/10/2008 20:02:00

5878 